\title{
An Integrated Approach to Vehicle Recycling Facilities
}

\author{
Naif A. Alsaadi and Matthew J. Franchetti
}

\begin{abstract}
The Integrated Approach to Vehicle Recycling Facilities is a research proposal is designed to find out the most effective and efficient method that can be used to improve global end of life vehicle (ELV) recycling. The present world is concerned in achieving a balance between environmental protection and conserving resources to achieve sustainability in production. Therefore, ELV recycling is not only cost related but also aimed at reducing environmental intoxication and hence cut off unnecessary health hazards. Automotive recycling processes involve other processes that are collection, transportation de-pollution, dismantling, shredding, melting, and disposal.
\end{abstract}

Index Terms—De-pollution, dismantling, shredding, ELV.

\section{LITERATURE REVIEW}

\section{A. Reverse Logistics}

The logistics process usually begins from raw materials, up to the end process at the consumer level. On the other hand, reverse logistics is concerned with procedures and methods of recycling and dismantling, maintenance and repairs for product and materials. All these processes and activities in reverse logistics systems incur costs and must be included in the design of the system. The processes involved are labor costs, transportation, and disposal of products, product collection, remanufacturing and recycling of the products [1]. This results in reduced metallic fraction of these automobiles, and there is an increase in components of glass, fabrics and polymers. There is a high demand for metal than it is there for these other materials where it emerges from the shredder. Fig. 1 , is a diagram for reverse logistics.

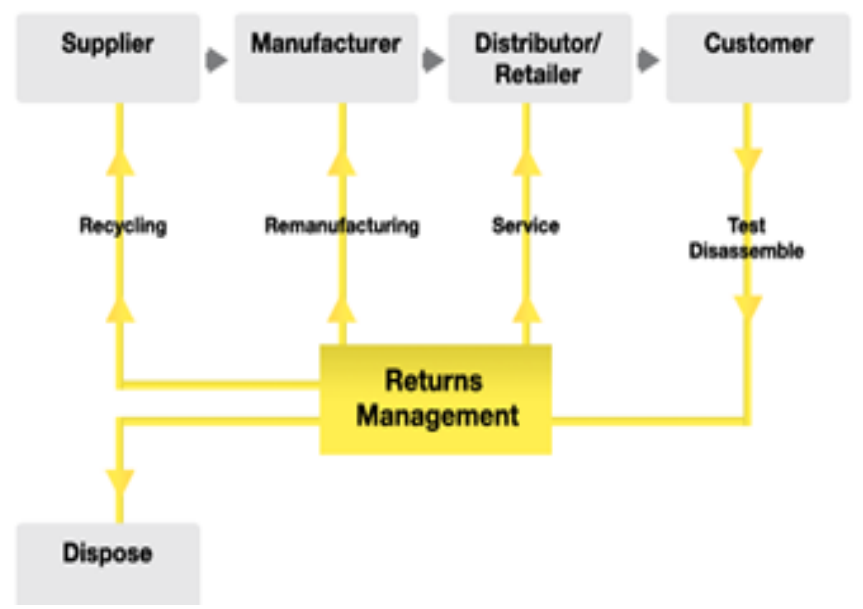

Fig. 1. Reverse logistics paradigm.

Manuscript received November 13, 2015; revised February 19, 2016.

The authors are with the Department of Mechanical, Industrial and Manufacturing Engineering, University of Toledo, Toledo, USA (e-mail: Naif.Alsaadi@rockets.utoledo.edu, matthew.franchetti@utoledo.edu).

\section{B. ELV Recycling}

Automotive recycling involves three areas namely working components, recoverable components, and unrecoverable components. As cited by an article from Holden Australia, the recycling process begins by removing hazardous materials from the car, draining all fluids and removing all pyrotechnic devices such as airbags. The following table shows different manufacturers and their procedures regarding ELVs recycling.

TABLE I: PROCEDURE OF RECYCLING PER MANUfACTURERS

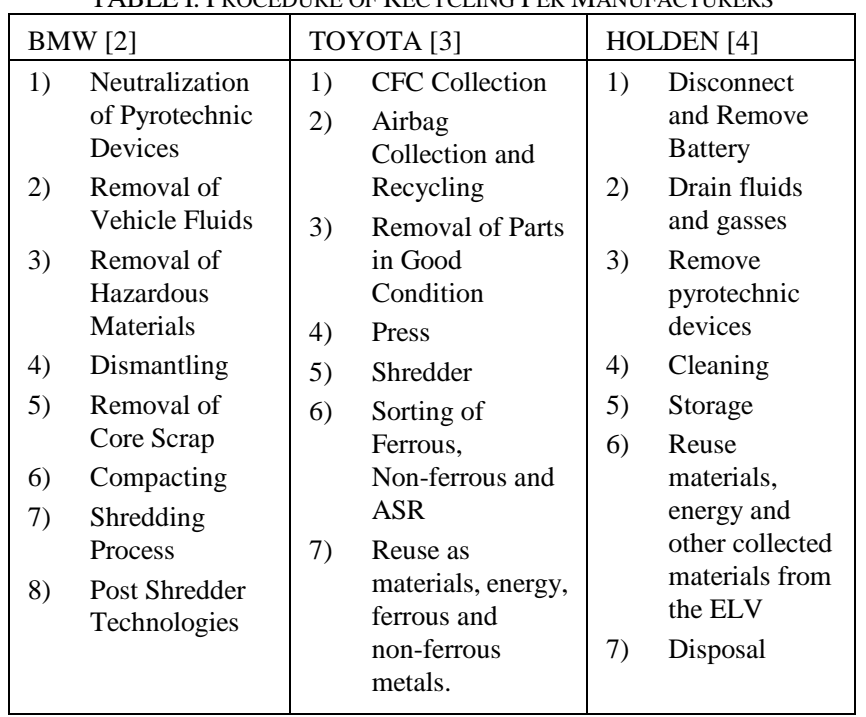

\section{Cost of Recycling}

As the design of modern vehicles is concerned more on efficiency, lighter materials are used. This leads to reduced metallic fraction of these automobiles, and there is an increase in components of glass, fabrics and polymers. There is a high demand for metal than it is there for these other materials where it emerges from the shredder. Since disposal of materials is done through landfills, when the cost of landfill is high the cost of operation of the shredder may not cover the costs but if the cost of landfill is low, then only a fraction of the amount operates the shredder [5].

During the computation of this cost, the dismantler must consider other factors like the cost of getting the ELV, the cost of extraction, storage and distribution of parts that can be sold, the cost of extracting and removing parts that are not required by the shredder in the stripped car, the price of used parts that can be sold and the price of the car would be sold in a stripped state. The dismantler and shredder are not in same the company, and others factors need to be considered. They are the cost of operating the shredder and the ferrous separator, the cost of the hulk to be obtained, the asking price for the mixed non-ferrous blend, cost of disposal of shredder residue, and the price the shredder gets from processed steel. These 
factors are essential in the determination of the cost of operating the reverse logistics facility [5].

\section{Automotive Recycling Association}

Countries that are conscious on the problem of vehicle recycling have joined the Automotive Recycling Association to share ideas on ELV recycling. There are however different legislations and directives at various places governing these recycling processes as showing in table 2 . Focus on the recycling must be with the producer who can be either the vehicle manufacturer or professional importer of the vehicle for the laws to be effective.

TABLE II: COUNTRIES AND THEIR DIRECTIVES REGARDING ELVS

\begin{tabular}{|c|c|c|}
\hline \multirow[t]{3}{*}{ Europe [6] } & Legislation & Directive 2000/53/EC \\
\hline & Recovery Rates & $\begin{array}{l}85-95 \% \text { by } 2015 \\
5 \% \text { of ASR will go to landfill }\end{array}$ \\
\hline & The Law & $\begin{array}{l}\text { - Manufacturers must reduce the use of hazardous materials when designing or producing a } \\
\text { vehicle } \\
\text { - Emphasize on increasing the use of recycled materials } \\
\text { - Producers must use ISO guidelines for labelling the parts } \\
\text { - Collection of ELVs and deadlines for material recovery will be implemented } \\
\text { - permits must be obtained by dismantlers }\end{array}$ \\
\hline \multirow[t]{3}{*}{ Japan [7] } & Legislation & End of Life Vehicle Recycling Law \\
\hline & Recovery Rates & $85-95 \%$ by 2015 \\
\hline & The Law & $\begin{array}{l}\text { - A network must be established between car owners, ELV collecting business, manufacturers } \\
\text { and car importers to recycle ELVs properly } \\
\text { - Fees shall be paid upon purchasing new cars for those who purchase new cars from January } \\
\text { 2005, the case of disposing of cars without undergoing a periodic inspection, fees shall be } \\
\text { paid to ELV - collecting businesses when ELVs are handed over to them }\end{array}$ \\
\hline \multirow[t]{3}{*}{ Korea [8] } & Legislation & Act for Resource Recycling of Electrical and Electronic Equipment and Vehicles \\
\hline & Recovery Rates & $85-95 \%$ by 2015 \\
\hline & The Law & $\begin{array}{l}\text { - Restriction on the use of hazardous materials } \\
\text { - Improvement of materials and structure in products for easy recycling } \\
\text { - Separate collection of waste products for easy recycling } \\
\text { - Manufacturers or importers of vehicles receive an annual recycling rate by joining a vehicle } \\
\text { association } \\
\text { - Establishment of Recycling Information Network }\end{array}$ \\
\hline \multirow[t]{3}{*}{ Canada [9] } & Legislation & Canadian Auto recyclers Environmental Code \\
\hline & Recovery Rates & $94 \%$ recovery rate \\
\hline & The Law & $\begin{array}{l}\text { - Dismantling and Recycling of vehicles is more environmentally friendly } \\
\text { - Manufacturers are mandated to produce new vehicles with a view to increased recyclability }\end{array}$ \\
\hline \multirow[t]{3}{*}{ United States [10] } & Legislation & Automobile Recycling Study Act of 1991 (HR 3369). \\
\hline & Recovery Rate & $95 \%$ recovery rate \\
\hline & The Law & $\begin{array}{l}\text { - Identify potential problems in recycling and develop new solutions to the identified problems } \\
\text { - Recyclability must be incorporated in the plans and designs of newly manufactured autos } \\
\text { - Determine possible substitutes to hazardous substances used in vehicles. } \\
\text { - Create design standards for autos that would result in phasing out of hazardous and } \\
\text { non-recyclable materials } \\
\text { - Examine methods for creating more recyclable plastics for use in autos }\end{array}$ \\
\hline
\end{tabular}

\section{E. Conceptual Models Used in ELV Recycling}

Research has used Reverse Logistics as a tool to formulate mathematical models that support the Recovery Plan and Disassembly sequence in automobiles. Technical cost models of ELV processing operators that are developed show that there is $80 \%$ recycling rate by removing $14 \%$ of ELV mass. Through a developed simulation, which examines future changes by the year 2015, the results indicated that recycling
95\% target is unattainable unless changes are done in vehicle material composition [11].

The costs of each process in de-manufacturing facilities are determined to create the processed model for the project. In the formulation of the model, each of the cost can be used as a variable and is used to determine overall benefits associated with the establishment of the de-manufacturing facilities. A conceptual model was developed to minimize the costs of setting up the network and raw materials flow between 
different facilities. It is assumed that the whole network is conducted by the manufacturer and thus distributioncollection centers are also assumed [11].

There are four different modeling technique classifications that were identified namely; classification based on order type of flow, classification according to model type, classification according to objective function and uncertainty in Reverse Logistics [12].

\section{F. Summary of Literature Review}

Reverse Logistics is the control process flow of raw materials, inventory and finished goods from the consumer to the origin to recapture value or properly disposed waste. It is a foundation mathematical model formulated for ELV network design and in the automotive industry it minimizes cost and optimizes material recovery. Reverse Logistics is based on previous research that sought to obtain optimum solution which included techniques like Mixed Integer Programming, Non-Linear Programming and order type of flow models, methods that consider uncertainty, and Objective function models. Raw materials that are retrievable from ELVs in the de-manufacturing network are identified and operational standards of spare parts obtained from ELVs are determined. Raw materials that are retrievable from ELVs in the de-manufacturing network are identified and operational standards of spare parts obtained from ELVs are determined.

\section{MethodOLOGY}

The project involves a wide scope in deriving the solution to the problem of environmental pollution that is realized from poor disposal mechanisms of ELVs. The project put more emphasis on the different methods and techniques that are known to be effective in developing an integrated vehicle recycling facility. It also focuses on the previous research about to the disposal techniques of ELVs, therefore, relies on secondary research. Qualitative and quantitative approaches are involved in deriving a concrete solution. Fig. 2, illustrates the key steps that involved in the design of an effective development methodology.

\section{A. ELV Recycling Facility}

The recycling of ELVs is of great concern as it poses a threat to the environment but can be managed because materials can be recovered from vehicles through the recycling process and as a result save resources and energy. These recovered materials through the Reverse Logistics system are the used as new raw materials.

\section{B. Research Material}

The project is developed from already existing recycling facilities, and concepts are derived from other related materials.

\section{Identification of the Problem and Project Objectives}

The project problem and objectives are derived from research materials that are obtained from the industry and also include secondary sources that have been used in previous research. The statement of the problem would be: What is the optimal vehicle recycling network model that can be established economically and environmentally friendly?
The main objectives of the study are the following:

1) To identify automobile materials, suppliers, and processes suitable for de-manufacturing operations.

2) To establish baseline cost metrics for automobile de-manufacturing, reuse, recycling and disposal.

3) To identify the optimal locations of processing facilities that would minimize the cost.

4) To be able to create an optimal vehicle recycling network model that would minimize cost of processing and logistics and at the same time avoid hazard in the environment.

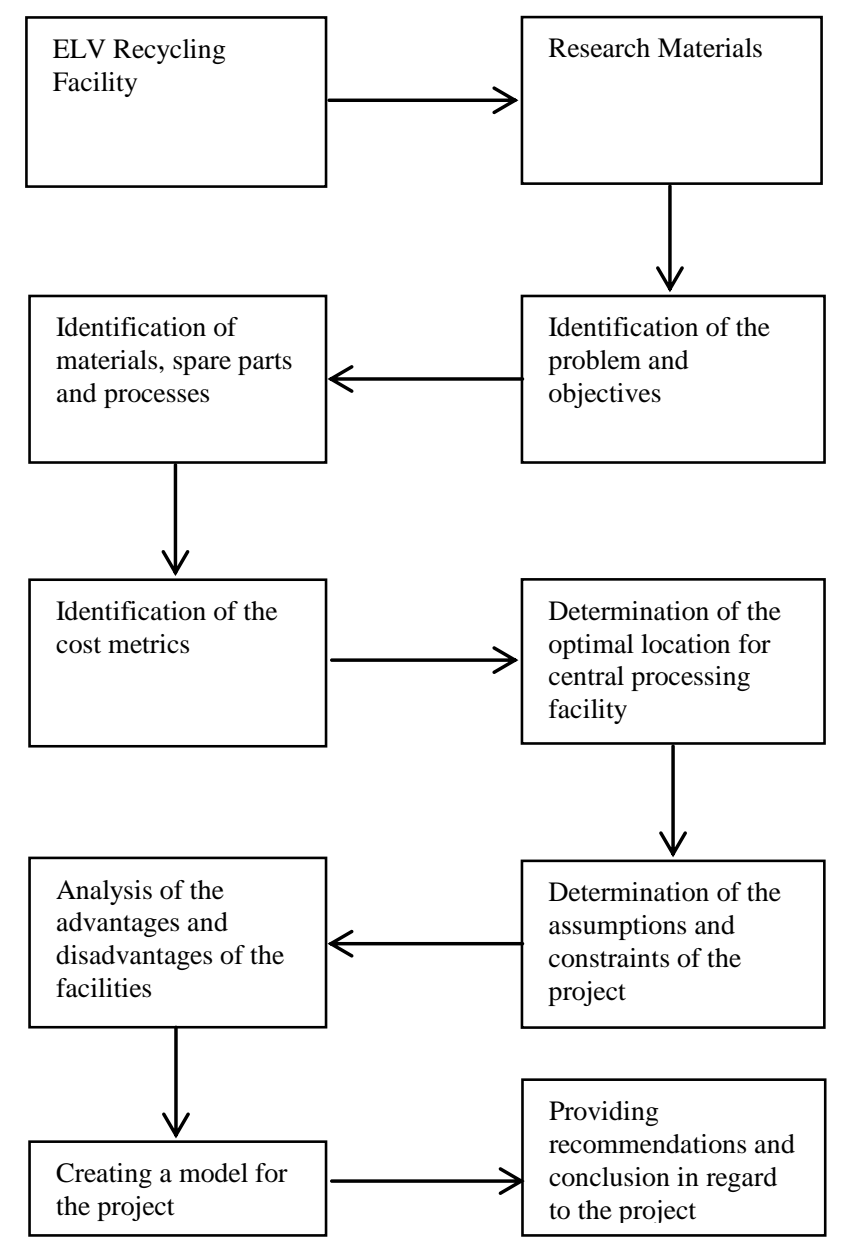

Fig. 2. Methodology paradigm.

\section{Identification of Materials, Processes and Spare Parts}

Raw materials that are retrievable from ELVs and processes in the de-manufacturing network are identified, and operational standards of spare parts obtained from ELVs are determined. The following table can be used to illustrate how the raw materials and the processes can be determined.

\section{E. Identification of the Cost Metrics}

The costs of each process in vehicle recycling facilities are determined to create the processed model for the project. In the formulation of the model, each of the cost can be used as a variable and is used to determine overall benefits associated with the establishment of the facilities. The following table can be used to illustrate how the possible costs incurred during the ELV recycling are determined.

\section{F. Determination of the Optimal Location for the Central Facility}


The research determines the practices that leads to the optimal locations of processing facilities based on the cost metrics and literature available. It leads to the network facilitating market of the scrap metal and boost the need for disposal of vehicles through the facility.

TABLE III: IDENTIFICATION OF MATERIALS AND PROCESSES

\begin{tabular}{|c|c|c|}
\hline Details & Materials & Source \\
\hline \multirow[t]{4}{*}{$\begin{array}{l}\text { Materials, and } \\
\text { Spare Parts }\end{array}$} & Recycled Vehicle Fluids & $\begin{array}{l}\text { Check local directory for end users of Vehicle Fluids (Yellow Pages, } \\
\text { interview with local wreckers) }\end{array}$ \\
\hline & Hazardous Materials from ELV & $\begin{array}{l}\text { Check with local govermment departments if there are any special } \\
\text { procedures in dealing with hazardous materials from ELV (Online } \\
\text { and Interview with local govermment units) }\end{array}$ \\
\hline & Recycled Spare Parts from ELV & $\begin{array}{l}\text { Check local directory for end users of recycled Spare Parts } \\
\text { (interview with local wreckers) }\end{array}$ \\
\hline & $\begin{array}{l}\text { ELV Car Chassis, Compacted Scrap } \\
\text { Metal Shredded Materials (Ferrous and } \\
\text { Non-ferrous) }\end{array}$ & $\begin{array}{l}\text { Check local directory for shredders and compacting facilities in the } \\
\text { area. It would be helpful to ask local car dealers if they are acquiring } \\
\text { ELV from customers and how they deal with this }\end{array}$ \\
\hline \multirow[t]{9}{*}{ Process } & Acquiring ELV & $\begin{array}{l}\text { Ask Car dealers if they are acquiring ELV, Check local directory for } \\
\text { car junk yards on how they acquire ELV }\end{array}$ \\
\hline & Neutralization of Pyrotechnic Devices & Inquire about this with car dealers, car wreckers and car junk \\
\hline & Removal of Vehicle Fluids & Inquire about this with car dealers, car wreckers and car junk yard \\
\hline & Removal of Hazardous Materials & Inquire about this with car dealers, car wreckers and car junk yard \\
\hline & Dismantling & Inquire about this with car dealers, car wreckers and car junk yard \\
\hline & Removal of Core Scrap & Inquire about this with car dealers, car wreckers and car junk yard \\
\hline & Compacting & $\begin{array}{l}\text { Inquire about this with car dealers, car wreckers and car junk yard. } \\
\text { Research on compacting facilities for cars }\end{array}$ \\
\hline & Shredding Process & $\begin{array}{l}\text { Inquire about this with car dealers, car wreckers and car junk yard. } \\
\text { Research on Shredding facilities for cars }\end{array}$ \\
\hline & Post Shredder Technologies & $\begin{array}{l}\text { Inquire about this with scrap metal dealers and shredding facilities } \\
\text { or even local waste management unit }\end{array}$ \\
\hline
\end{tabular}

TABLE IV: PossiBLE COSTS INCURRED DURING THE ELV RECYCLING

\begin{tabular}{|c|c|}
\hline Cost Metric & Source \\
\hline Cost of Acquiring ELV & $\begin{array}{l}\text { Interview with car dealers (if they are } \\
\text { de-manufacturing), car wreckers, car } \\
\text { junk yard }\end{array}$ \\
\hline $\begin{array}{l}\text { The cost of extracting, } \\
\text { storing, and distributing the } \\
\text { parts that can be sold }\end{array}$ & $\begin{array}{l}\text { Interview with car wreckers and car } \\
\text { junkyard }\end{array}$ \\
\hline Price of Parts that can be sold & $\begin{array}{l}\text { Interview with car wreckers and spare } \\
\text { part auto resellers }\end{array}$ \\
\hline $\begin{array}{l}\text { Cost of extracting and } \\
\text { removing the parts that the } \\
\text { shredder does not want in the } \\
\text { stripped car }\end{array}$ & $\begin{array}{l}\text { Interview with car dealers (if they are } \\
\text { de-manufacturing), car wreckers, car } \\
\text { junk yard }\end{array}$ \\
\hline $\begin{array}{l}\text { Price of the stripped car that } \\
\text { would be sold to the shredder }\end{array}$ & $\begin{array}{l}\text { Interview with car shredder facility, car } \\
\text { wreckers and car junk yards }\end{array}$ \\
\hline Cost of metal scrap & Interview with metal scrap dealers \\
\hline $\begin{array}{l}\text { Operating cost of the shredder } \\
\text { and ferrous separator }\end{array}$ & Interview with shredding facilities \\
\hline $\begin{array}{l}\text { Disposal cost of Automotive } \\
\text { Shredder Residue }\end{array}$ & $\begin{array}{l}\text { Interview with shredding facilities and } \\
\text { local waste management unit }\end{array}$ \\
\hline $\begin{array}{l}\text { Asking Price of shredded } \\
\text { ferrous metal blend }\end{array}$ & $\begin{array}{l}\text { Interview with scrap metal dealers and } \\
\text { shredders }\end{array}$ \\
\hline $\begin{array}{l}\text { Asking Price of the mixed } \\
\text { non-ferrous metal blend }\end{array}$ & $\begin{array}{l}\text { Interview with recyclers that deal with } \\
\text { non-ferrous metal blend }\end{array}$ \\
\hline $\begin{array}{l}\text { Cost of Acquiring a new } \\
\text { shredder }\end{array}$ & $\begin{array}{l}\text { Research online and interview with } \\
\text { shredder facilities }\end{array}$ \\
\hline $\begin{array}{l}\text { Cost of acquiring a ferrous } \\
\text { separator }\end{array}$ & $\begin{array}{l}\text { Research online and interview with } \\
\text { shredder facilities }\end{array}$ \\
\hline
\end{tabular}

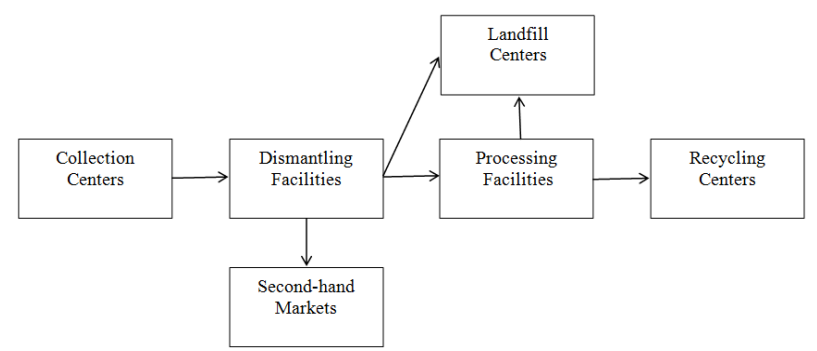

Fig. 3. Proposed recycling network.

\section{G. Analysis of Advantages and Disadvantages of an Integrated Recycling Facility}

The advantages of an integrated system of vehicle recycling facilities include reduced environmental pollution by possible recyclable wastes. The facility will increase the willingness of vehicle owners to adopt good disposal mechanisms. Thu the vehicle owners will earn some income in the process of the disposal and create job opportunities [13]. Raw materials are obtained from this process and leads to standardization of scrap metals and spare parts.

The integrated vehicle recycling facilities has a shortcoming. The prices of spare parts will decrease due to an introduction of many spare parts to the market.

\section{H. Determination of the Constraints and the Assumptions of the Project}

Limiting factors such as cost, sensitization, and review of legal requirements are evaluated. Constraints can result from government regulations which are based on ideal conditions in an environment where the process takes place.

\section{Creation of the Model Project}

The proposed model is mathematically formulated to establish recycling network for ELVs and is comprised of preliminary and actual operations necessary. The model constitutes the parameters involved in the implementation of the project and defines the optimum locations and the number of processing facilities and allocates materials flows within the network. The model inputs are cost of acquiring the ELV, cost of cost of Processing ELV before Compacting, cost of compacting ELV, cost of Shredding ELV, and cost of transportations within the network. The model objective function would be the optimal cost of the facilities that included in the network. The structure of the proposed network for recycling end-of-life vehicles is presented in Fig. 3.

\section{CONCLUSION}

The logistics process usually begins from raw materials, up to the end process at the consumer level. On the other hand, reverse logistics is concerned on procedures and methods of recycling and dismantling, maintenance and repairs for product and materials. All these processes and activities in reverse logistics systems incur costs and must be included in the design of the system. The project put more emphasis on the different methods and techniques that are known to be effective in developing an integrated vehicle recycling facility.

\section{FUTURE WORK}

Future work will include the development of the optimization model on a place where ELV laws and legislations are implemented. It will also be directed to compare between the cost of de-manufacturing versus traditional methods. A sensitivity analysis would be used to understand the overall change in Vehicle recycling economics.

\section{REFERENCES}

[1] Sanket. (2009). Reverse logistics. [Online]. Available: http://www.slideshare.net/sanket_123/reverse-logistics-presentation

[2] BMW Group. (2009). Vehicle recycling: Focusing on sustainability. [Online]. 
http://www.bmw.com/com/en/owners/service/_shared/pdf/2009_recy cling.pdf

[3] Toyota Motor Corporation. (2014). Vehicle recycling. [Online]. Available:

http://www.toyota-global.com/sustainability/report/vehicle_recycling/

[4] Autoparts Recycle Association of Australiar; Greenfleet; Holden. (2014). Auto parts recycling: A guide to the future. [Online]. Available: http://www.holden.com.au/resources/documents/recycling_guide.pdf

[5] F. R. Field, "The recycling of automobiles: Conflicting environmental objectives in a competitive marketplace," presented at KIET International Seminar on Korea's Auto Industry, 1993.

[6] N. Kanari, J. Pineau, and S. Shallari. End-of-life vehicle recycling in the European Union. [Online]. Available: http://www.tms.org/pubs/journals/JOM/0308/Kanari-0308.html

[7] Ministry of Economy, Trade and Industry. (2005). End of Life Vehicle Recycling Law. [Online]. Available: http://www.meti.go.jp/policy/recycle/main/english/law/end.html

[8] RSJ Technical Consulting. (2007). What is Korea RoHS. [Online]. Available: http://www.rsjtechnical.com/WhatisKoreaRoHS.htm

[9] Automotive Recyclers of Canada. (2011). A National Approach to the Environmental Management of End-of-life Vehicles in Canada. R[Online].

Available: http://autorecyclers.ca/2011/a-national-approach-to-the-environmenta 1-management-of-end-of-life-vehicles-in-canada/

[10] J. Staudinger and G. A. Keoleian. (2001). Management of End of Life Vehicles in the US. [Online]. Available: http://css.snre.umich.edu/css_doc/CSS01-01.pdf

[11] M. Zarei, S. Mansour, A. Kashan, and B. Karimi, "Designing a reverse logistics network for end-of-life vehicles recovery," Mathematical Problems in Engineering, vol. 16, 2010.

[12] H. Elwany, N. Fors, N. Harraz, and N. Galal, "Reverse logistics network design: Review of models," in Proc. 37th International Conference on Computers and Industrial Engineering, vol. 9, 2007.

[13] F. Mathieux and D. Brissaud, "End-of-life product-specific material flow analysis. Application to aluminum coming from end-of-life commercial vehicles in Europe," Resources, Conservation and Recycling, pp. 92-105, 2010.

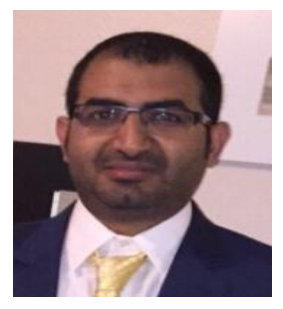

Alsaadi, Naif Abdullah was born in Makkah, Saudi Arabia in 1981. Naif has completed a number of degrees and diplomas in various fields. A bachelor's degree in electrical engineering was acquired from King Abdul-Aziz University in Saudi Arabia in 2004. Similarly, a diploma in instrument maintenance of desalination \& power plants was received from Higher Institute for Water and Power Technologies in Saudi Arabia in
2005. Naif also was awarded with a masters degree in industrial engineering by King Abdul-Aziz University in Saudi Arabia in 2009. In addition, Naif received a masters degree in industrial engineering from Houston University in Texas in 2013 plus a diploma in intensive English program from the same University, acquired in 2011. A PhD degree in industrial engineering is underway at Toledo University in Ohio, which was commenced in Fall 2013.

Over the years, he has had a number of opportunities that have provided him with diverse work experiences in various fields and tasks. Between 2004 and 2005, he worked as an instrument \& electronics workshop supervisor at Saline Water Conversion Corporation. From 2005 and 2009, he worked as a loss prevention engineer at Saudi Electricity Company and between 2009 and 2010 he worked as a lecturer in the Industrial Engineering Department.

Besides the educational expertise and the various job experiences, $\mathrm{Mr}$. Naif is also popular for his prowess in programming in areas such as Microsoft office, lingo and arena. In addition, Mr. Naif has also engaged in various training courses including fire safety management, job safety management, safety best practices in engineering and business writing, among many others.

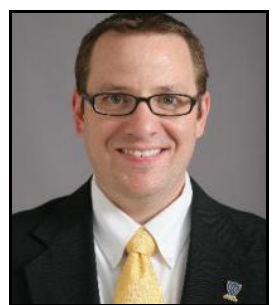

Franchetti Matthew was born in Ohio, USA in 1975. Franchetti received his Ph.D. (2003) in industrial engineering and MBA (2000) from the University of Toledo, USA

$\mathrm{He}$ is an associate professor of mechanical, industrial and manufacturing engineering and the director of undergraduate studies of the mechanical and industrial engineering programs at The University of Toledo. He also is the director of the environmentally conscious design and manufacturing laboratory and principal investigator of the business waste reduction assistance program, a joint effort with the Lucas County Solid Waste Management District. Additionally, he is working as the principal investigator with the Health Science Campus at the University of Toledo to improve the business processes for renal implant patients by applying six-sigma concepts. He has worked as an industrial engineer and technical manager for the U.S. Postal Service in Washington DC, Pittsburgh, PA, and Columbus, $\mathrm{OH}$ and has conducted research at Daimler Chrysler, General Motors, and Ford before joining the MIME Department in the Fall of 2007.

Dr. Franchetti is certified six-sigma black belt from the American Society of Quality (ASQ) and has consulting and research experience with over 25 companies across the country. He has also served as an expert witness in legal proceedings related to human factors and ergonomics. 